\title{
The Knowledge, Attitude, and Behavior of Hospitalized Patients' Families in the Effort to Prevent COVID-19
}

\author{
Anies Dewi Wirati Indraswari ${ }^{1} \quad$ Abdul Aziz $^{2,3}$ Meircurius Dwi Condro Surboyo 4 (잉 \\ ${ }^{1}$ Clinical Ners at Medical Department, Fatmawati Hospital, Cilandak, \\ South Jakarta, Indonesia \\ 2 Department of Education and Research, Fatmawati Hospital, \\ Cilandak, South Jakarta, Indonesia \\ ${ }^{3}$ Department of Public Health, Sekolah Tinggi Ilmu Kesehatan \\ Masyarakat, Indonesia \\ ${ }^{4}$ Department of Oral Medicine, Faculty of Dental Medicine, \\ Universitas Airlangga, Surabaya, Indonesia \\ J Health Allied Sci ${ }^{\mathrm{NU}} 2022 ; 12: 113-118$. \\ Address for correspondence Anies Dewi Wirati Indraswari, SKep, \\ Ners, Clinical Ners at Medical Department, Fatmawati Hospital, Jl. RS. \\ Fatmawati Raya No. 4, Cilandak, South Jakarta 12430, Indonesia \\ (e-mail: anies.dewi36@yahoo.com).
}

Introduction The coronavirus disease-2019 (COVID-19) pandemic has also hit Indonesia. Until September 2020, cases continued to increase with the highest number in Jakarta. The right behavior needs to be followed to prevent COVID-19; this aspect has a strong relationship with knowledge and attitude. This study aimed to analyze the relationship between the knowledge, attitudes, and behavior of hospitalized patients' families in Fatmawati Hospital, Jakarta, in an effort to prevent COVID-19.

Materials and Methods A cross-sectional study was conducted on 300 respondents using a self-administered questionnaire to assess their knowledge, attitude, and behavior about COVID-19. The relationship between knowledge, attitude, and behavior was analyzed using the chi-square test with $p<0.05$.

Keywords

Results Most of the participants responded to the questionnaire showing a good knowledge, attitude, and behavior related to the efforts to prevent COVID-19. No relationship was present between knowledge, attitude, and behavior in an effort to prevent COVID-19 ( $p=0.414$ and $p=0.165)$.

Conclusion The hospitalized patients' families exhibited an adequate level of knowledge, attitude, and preventive behaviors toward COVID-19.

\section{Introduction}

The coronavirus disease-2019 (COVID-19) has spread to various countries including Indonesia. Jakarta became the first city to report cases, with two cases reported on March 2, 2020. As of September 12, 2020, the spread of cases had reached 34 provinces in Indonesia with a death rate of
4.68\%. ${ }^{1}$ Various efforts have been made by the government to prevent COVID-19 transmission. ${ }^{2}$ However, during the 6 months of this pandemic, cases continued to increase. ${ }^{3,4}$

Hospitalized patients are very susceptible to carrying the virus home and transmitting it to other members of their families. ${ }^{5}$ Both hospitalized patients and their families must have the knowledge, display an appropriate attitude and
DOI https://doi.org/ $10.1055 / \mathrm{s}-0041-1736271$. ISSN 2582-4287.

\footnotetext{
(c) 2021. Nitte (Deemed to be University). All rights reserved. This is an open access article published by Thieme under the terms of the Creative Commons Attribution-NonDerivative-NonCommercial-License, permitting copying and reproduction so long as the original work is given appropriate credit. Contents may not be used for commercial purposes, or adapted, remixed, transformed or built upon. (https://creativecommons.org/ licenses/by-nc-nd/4.0/)

Thieme Medical and Scientific Publishers Pvt. Ltd., A-12, 2nd Floor, Sector 2, Noida-201301 UP, India
} 
behavior, and understand the preventive action needed to avoid the infection. ${ }^{6}$ Preventive actions for COVID-19 transmission include washing hands with soap, ${ }^{7}$ following guidelines on cough/sneeze etiquette, wearing a mask, ${ }^{8}$ and maintaining distance when interacting with others. ${ }^{9}$ This behavior requires knowledge and action and has implications for people's lives and also in public health. ${ }^{10}$ Behavior is a human reaction due to cognitive (knowledge), affective (attitude), and psychomotor activities, which are interrelated. ${ }^{11}$ If one of these aspects experiences obstacles, then other aspects of behavior are also disturbed. ${ }^{12}$ Therefore, it is necessary to conduct research to find out the knowledge and attitude related to COVID-19 because it will directly affect people's behaviors.

The hospitals have become hotspots for COVID-19 infection, and hundreds of healthcare workers have been infected, ${ }^{13}$ and it is possible to spread the infection from health workers to non-infected patients and the patients' families. ${ }^{14}$ Moreover, patients and families must have good knowledge about COVID-19 precautions because both are at risk of transmitting COVID-19 to nearby patients and health workers if they do not behave properly. This research was first conducted in Fatmawati Hospital since the COVID-19 pandemic began in March 2020 to describe the knowledge, attitudes, and behavior of the hospitalized patient's family in Fatmawati Hospital, Jakarta, in an effort to prevent COVID-19.

\section{Materials and Methods}

\section{Ethical Concern}

This research has been approved by the Ethics Committee and Bagian Pendidikan dan Penelitian (DIKLIT)-Fatmawati Hospital with registered number 01.01/VII.2/418/2020.

\section{Study Participants}

The cross-sectional survey was conducted from July to September 2020 in the care unit at Teratai, Fatmawati Hospital using a questionnaire. The participants were the patients' families, who accompanied a patient being treated in the care unit. The participants including in this study were aged at least 20 years, lived in Jakarta, Bogor, Depok, Tangerang, and Bekasi city and agreed to become a respondent.

\section{Sample Size}

The sample size was measured using the proportioned formula.

$$
n=\operatorname{deffx} \frac{N p q}{\frac{d^{2}}{1.96^{2}}(N-1)+p q}
$$

The deff (the design effect) $=1 ; N$ (population size) $=1336 ; p$ (awareness rate) $=30 \% ; q=1-p ; \alpha=0.05 ; d$ (tolerance rate $)=2 \%$. An extra $10 \%$ was added for questionnaires that were filled wrongly, giving a calculated minimum sample size of 274. Families of three hundred patients participated in the study.

\section{Questionnaire}

The self-administered questionnaire contained three sections consisting of 21 questions related to knowledge, attitude, and behavior in an effort to prevent COVID-19.

The knowledge section consisted of 10 questions, adopted from Bhagavathula et al, 2020, and was related to general symptoms, transmission, prevention, and factors that aggravate the prognosis of COVID-19. ${ }^{15}$ Respondents answered this section by selecting the answer to each question with a "yes" or "no." Each question scored as 1 if the respondent selected the right answer. The level of knowledge was divided into two categories, value $\geq 6$ indicated good knowledge and $<6$ indicated poor knowledge.

The attitude section consisted of five questions, adopted from Zhang et al, 2020, and covered the respondents' feelings of anxiety, disappointment, fatigue, irritability, and difficulty sleeping. ${ }^{16}$ The attitude questions were provided values using the Likert scale ranging from 1 (never), 1 (rarely), 2 (often), to 3 (always).

The behavior sections consisted of six questions related to wearing a mask, washing hands, avoiding crowds, staying at home, and reducing outdoor activities, maintaining social distancing, and doing exercise. The behavior was valued using a Likert scale ranging from 1 (never), 1 (rarely), 2 (often), to 3 (always).

\section{Questioner Validity and Reliability}

The questionnaire data obtained were analyzed using the validity test (Pearson correlation) and reliability test (Cronbach's alpha) with IBM SPSS Statistic version 23. The validity test used Pearson's product moment correlation, with $p<0.05$.

\section{Data Analysis}

The obtained data were coded, validated, and analyzed using IBM SPSS Statistic version 23. Descriptive analysis was applied to calculate frequencies and proportions. The Chisquare test was used to investigate the relationship of knowledge and attitude to the behavior aspect. A $p$-value of less than 0.05 was considered statistically significant.

\section{Results}

\section{Respondent Characteristics}

Most respondents who participated in this study were females $(58.7 \%)$, aged $>40$ years $(31.7 \%)$, with senior high school education (52.3\%) ( - Table 1).

\section{Knowledge Aspect}

Most of the respondents knew the symptoms of COVID-19, such as fever, dry cough, weakness, body ache (92.7\%) and flu, sneezing, and a runny nose (81.3\%). The respondents knew factors that affect the prognosis of COVID-19, such as being elderly (93.7\%) and history of heart disease (84.0\%); modes of transmission, such as droplet transmission (93.7\%); and ways of preventing COVID-19, such as wearing a mask (99.7\%), washing hands with soap (99.3\%), and isolation after contact with a COVID-19 patient (95.7\%) (-Table 2). However, more 
Table 1 Respondent characteristics

\begin{tabular}{|l|l|}
\hline Characteristic & $N(\%)$ \\
\hline Gender & $124(41.3)$ \\
\hline Male & $176(58.7)$ \\
\hline Female & $96(31.7)$ \\
\hline Ages & $91(30.3)$ \\
\hline $20-30$ & $113(38)$ \\
\hline $30-40$ & $23(7.7)$ \\
\hline$>40$ & $29(9.7)$ \\
\hline Educational background & $157(52.3)$ \\
\hline Elementary school & $91(30.3)$ \\
\hline Junior high school &
\end{tabular}

than half of the respondents (59.0\%) did not know that COVID-19 is a contagious disease because people with COVID-19 could still transmit it without experiencing any signs and symptoms. The majority of respondents (97.7\%) had good knowledge of COVID-19 and only $2.3 \%$ had poor knowledge of COVID-19.

\section{Attitude Aspect}

The respondents had different reactions when they heard about COVID-19 in the news, such as often feeling anxious (38.7\%), rarely getting angry (40.7\%), never feeling tired (38\%), always being disappointed when COVID-19 cases continued to increase (36.3\%), and never having sleeping trouble when hearing the news of COVID-19 (55.3\%) (- Table 3).

\section{Behavior Aspect}

Behaviors related to the effort to prevent COVID-19 included most respondents always wearing a mask when leaving the
Table 3 The attitude of respondent related to COVID-19 prevention

\begin{tabular}{|c|c|c|c|}
\hline Questions & Response & $N$ & Percentage \\
\hline \multirow{4}{*}{$\begin{array}{l}\text { Feel anxious when you } \\
\text { hear news about } \\
\text { COVID-19 }\end{array}$} & Never & 33 & 11.0 \\
\hline & Rarely & 78 & 26.0 \\
\hline & Often & 116 & 38.7 \\
\hline & Always & 73 & 24.3 \\
\hline \multirow{4}{*}{$\begin{array}{l}\text { Get angry easily when } \\
\text { you hear news about } \\
\text { COVID-19 }\end{array}$} & Never & 125 & 41.7 \\
\hline & Rarely & 122 & 40.7 \\
\hline & Often & 38 & 12.7 \\
\hline & Always & 15 & 5.0 \\
\hline \multirow{4}{*}{$\begin{array}{l}\text { Feel tired when you } \\
\text { think about news } \\
\text { about COVID-19 }\end{array}$} & Never & 114 & 38.0 \\
\hline & Rarely & 93 & 31.0 \\
\hline & Often & 64 & 21.3 \\
\hline & Always & 29 & 9.7 \\
\hline \multirow{4}{*}{$\begin{array}{l}\text { Feel disappointed } \\
\text { because the number of } \\
\text { sufferers of COVID-19 } \\
\text { continues to grow }\end{array}$} & Never & 43 & 14.3 \\
\hline & Rarely & 55 & 18.3 \\
\hline & Often & 93 & 31.0 \\
\hline & Always & 109 & 36.3 \\
\hline \multirow{4}{*}{$\begin{array}{l}\text { Difficulty sleeping } \\
\text { when hearing the news } \\
\text { of COVID-19 }\end{array}$} & Never & 166 & 55.3 \\
\hline & Rarely & 96 & 32.0 \\
\hline & Often & 23 & 7.7 \\
\hline & Always & 15 & 5.0 \\
\hline
\end{tabular}

house ( $88 \%)$, washing their hands with soap after leaving the house (84.3\%), avoiding crowds (64.7\%), staying at home and reducing outdoor activities (51.3\%), keeping a distance when meeting other people (61.3\%), and rarely exercising (40.3\%) (-Table 4).

Table 2 The knowledge of respondents related to COVID-19 prevention

\begin{tabular}{|l|l|l|}
\hline Questions & \multicolumn{2}{l|}{ Response } \\
\cline { 2 - 3 } & $\begin{array}{l}\text { True } \\
N(\%)\end{array}$ & $\begin{array}{l}\text { False } \\
N(\%)\end{array}$ \\
\hline Signs and symptoms of COVID-19 include fever, dry cough, weakness, and body aches & $278(92.7)$ & $22(7.3)$ \\
\hline Signs and symptoms of COVID-19 such as flu, sneezing, and runny nose & $244(81.3)$ & $56(18.7)$ \\
\hline Elderly are risk of getting COVID-19 infection & $281(93.7)$ & $19(6.3)$ \\
\hline People with a history of heart disease find it difficult to recover if they have COVID-19 & $252(84.0)$ & $48(16.0)$ \\
\hline Eating meat from wild animals such as bats can transmit COVID-19 infection & $235(78.3)$ & $65(21.7)$ \\
\hline People who are infected with COVID-19 can transmit it even though they have no symptoms & $123(41.0)$ & $177(59.0)$ \\
\hline Coronaviruses are transmitted through droplets & $281(93.7)$ & $19(6.3)$ \\
\hline Wearing mask can prevent the COVID-19 infection & $299(99.7)$ & $1(0.3)$ \\
\hline Washing hands with soap is able to prevent the COVID-19 infection & $298(99.3)$ & $2(0.6)$ \\
\hline The isolation for 14 days must be performed after contact with a COVID-19 patient & $287(95.7)$ & $13(4.3)$ \\
\hline
\end{tabular}


Table 4 The behavior of respondents related to COVID-19 prevention

\begin{tabular}{|c|c|c|c|}
\hline Questions & Response & $N$ & Percentage \\
\hline \multirow{4}{*}{$\begin{array}{l}\text { Wear a mask when } \\
\text { leaving the house }\end{array}$} & Never & 5 & 1.7 \\
\hline & Rarely & 1 & 0.3 \\
\hline & Often & 28 & 9.3 \\
\hline & Always & 266 & 88.0 \\
\hline \multirow{4}{*}{$\begin{array}{l}\text { Wash your hands after } \\
\text { leaving the house }\end{array}$} & Never & 6 & 2.0 \\
\hline & Rarely & 5 & 1.7 \\
\hline & Often & 36 & 12.0 \\
\hline & Always & 253 & 84.3 \\
\hline \multirow[t]{4}{*}{ Avoid crowds } & Never & 5 & 1.7 \\
\hline & Rarely & 31 & 10.3 \\
\hline & Often & 70 & 23.3 \\
\hline & Always & 194 & 64.7 \\
\hline \multirow{4}{*}{$\begin{array}{l}\text { Stay at home and } \\
\text { reduce outdoor } \\
\text { activities }\end{array}$} & Never & 11 & 3.7 \\
\hline & Rarely & 55 & 18.3 \\
\hline & Often & 80 & 26.7 \\
\hline & Always & 154 & 51.3 \\
\hline \multirow{4}{*}{$\begin{array}{l}\text { Keep your distance } \\
\text { when meeting other } \\
\text { people }\end{array}$} & Never & 6 & 2.0 \\
\hline & Rarely & 37 & 12.3 \\
\hline & Often & 73 & 24.3 \\
\hline & Always & 184 & 61.3 \\
\hline \multirow[t]{4}{*}{ Exercise regularly } & Never & 28 & 9.3 \\
\hline & Rarely & 121 & 40.3 \\
\hline & Often & 78 & 26.0 \\
\hline & Always & 73 & 24.3 \\
\hline
\end{tabular}

\section{The Relationship of Knowledge, Attitude, and Behavior}

The chi-square test showed no relationship between knowledge aspect and behavior-related COVID-19 $(p=0.414)$. Similarly, no relationship between attitude aspects of knowledge was observed $(p=0.165)$.

\section{Discussion}

COVID-19 has become a global health problem since early 2020. Until now, the spread of COVID-19 continues and a vaccine for this disease is limited. To inhibit or break the chain of the spread of COVID-19, the participation of all parties from the community, government, and health facilities is required. ${ }^{17}$ Knowledge, attitude, and behavior are regarded as having a significant influence on the understanding and taking of preventive measures and bridging the gap toward the delivery of health information. ${ }^{6}$ In this study, the majority of hospitalized patients' families had good knowledge (97.7\%). This excellent level of knowledge is expected to influence good preventive behavior as well. ${ }^{18}$ The results of this knowledge are in line with the results of research in several other countries that also used a questionnaire instrument for 240 to 6,989 respondents. Zhong stated that $90 \%$ of respondents in Hubei, China, had good knowledge about COVID-19. ${ }^{19}$ The knowledge was determined from the information obtained from the respondent. In the era of modernization, information is easily obtained in various ways. Socialization directly or through social media by the Government and related parties has been performed in the community. In addition, the citizen is also actively seeking information related to COVID-19 because it is serious, occurs globally, and has an impact on all aspects of life.

The knowledge was determined by the information obtained from the respondents. In the modern era, all information can be easily obtained in several ways. Socialization, directly or through social media, by the government and related parties has been performed in the community. In addition, the public is actively seeking information related to COVID-19 because it is serious, occurring globally, and impacting all aspects of life.

Although the hospitalized patients' families' knowledge was very good, $59 \%$ of the respondents did not know that people with COVID-19 could still be contagious even though they had no symptoms. The results of another study at the Medical Centre of Jimma University also stated that most of the respondents did not know that an asymptomatic individual could transmit the infection to other people. ${ }^{20}$ The rate of asymptomatic individuals with COVID-19 reached $70 \%$ in Jakarta in early September 2020 and this figure continues to increase compared with the previous month. This high number and public ignorance of the asymptomatic individuals could result in accelerating the transmission of COVID-19. ${ }^{21,22}$ Therefore, it is important to conduct socialization related to the definition and dangers of asymptomatic individuals by the government, health facilities, and health providers in the community.

In addition to knowledge aspects, individual healthy behavior is influenced by attitude aspects. Attitude relates to a person's feelings and emotions. The majority of respondents stated that they often feel anxious when they hear news about COVID-19 (38.7\%). Various studies in several countries affected by COVID-19 obtained the same results. Situations that cause anxiety during the COVID-19 pandemic include the large amount of news disseminated through various media platforms about sufferers of COVID-19 and the growing death rate. Conditions of uncertainty, economic difficulties, reduced social activities and social support due to quarantine policies, loss of family due to COVID-19, and social stigma against people with COVID-19 also add to public anxiety. ${ }^{23}$ At a higher level, anxiety can lead to body vigilance, errors in interpreting body sensations, and illness behaviors such as visiting doctors or hospitals even though not needed and collecting excessive personal protective equipment. $^{24}$ In the current pandemic condition, people often look for COVID-19 information on social media to reduce their fear, collect PPE (personal protective equipment), personal drugs, and vitamins excessively.

Anxiety and disappointment were the most common psychological responses in this study. This response can be 
dangerous to health if someone experiences it in excess. Anxiety and disappointment become a stimulus for the body to produce cortisol. When there is stress, the body will activate the hypothalamus, adrenal, and pituitary glands to secrete glucocorticoids through corticotropin-releasing hormone (CRH). Glucocorticoids affect the body's metabolism and heart function, as well as the immune response. ${ }^{25}$ Stress triggers the body's immune response by increasing the inflammatory response and stimulating inflammatory mediators so that a person becomes susceptible to infections.

Knowledge and good affectivity affect an individual's behavior. ${ }^{26}$ In this research, this condition confirmed how the respondents reflexed their knowledge and attitude into behavior to prevent COVID-19. This fact was confirmed by how the respondents turned their knowledge and affectivity into behavior and actions to prevent COVID-19. Wearing masks, washing hands, avoiding crowds, staying at home, reducing outdoor activities, maintaining social distancing, and exercising regularly were performed by most respondents; these actions are the key to preventing COVID-19 from spreading. The COVID-19 outbreak started very suddenly and has had a direct impact on all aspects of life. For its effective prevention, rapid dissemination of information is needed to shape peoples' behavior and help them understand this condition. Prevention is not only needed at a community level; a necessary and important aspect of prevention also exists at an individual level. ${ }^{27}$

The results of this study showed no relationship between knowledge and attitudes related to COVID-19. Zhong et al (2020) obtained different results, where respondents' knowledge could significantly decrease the risky behavior. ${ }^{19}$ Kebede et al (2020) showed that preventive behavior was better in respondents with higher knowledge. ${ }^{20}$ These differences can be caused by the characteristics and the number of respondents. The number of respondents in Zhong's study was 6,$910 ; 51.7 \%$ were 30 to 49 years old and $44 \%$ were undergraduate. While in this study, the number of respondents was $300 ; 38 \%$ were aged over 40 years, and $52.3 \%$ had received senior high school level education. To date, no related studies that explain the influence of attitude aspects on COVID-19 prevention behavior are available. The majority of existing studies describe the attitude, psychosocial, and mental health in some countries as described above. Therefore, efforts to prevent the transmission of COVID-19 should not only focus on cognitive aspects or knowledge but also psychological support. Fatmawati Hospital has an important role in educating patients and their families about preventing the transmission of COVID-19 and providing support to reduce anxiety during this pandemic.

The overall knowledge, attitude, and behavior (washing hands with soap, following cough/sneeze etiquette, using a mask, and keeping a distance when interacting) of the hospitalized patient's family were higher and they already knew what to do to COVID-19. The level of knowledge about COVID-19 could still be contagious even though they had no symptoms, only $59 \%$ based on this survey. This high number and public ignorance of asymptomatic individuals could accelerate the transmission of COVID-19. The rapid dissemination of information is needed to shape people's behavior to understand this condition for its effective prevention.

The limitation of this study lies in the absence of patients with covid-19. This is due to limited access to the patient's family. However, the data obtained provide important information on the knowledge, attitudes, and behavior of patients' families. Knowledge becomes an important basis for people on how to behave in the face of these conditions. So, it is important to know how to describe knowledge, attitudes, and behaviors related to preventing COVID-19.

In conclusion, the hospitalized patients' families exhibited an adequate level of knowledge, attitude, and performance in preventive behaviors toward COVID-19. It is hoped that with the positive answers from the families of these patients, the spread of infection to the nearby patients, family, and health workers can be minimized to reduce the number of COVID19 occurrences.

\section{Conflict of Interest}

None declared.

Acknowledgments

The authors thank all the subjects involved in this study.

\section{References}

1 Tosepu R, Effendy DS, Ahmad LOAI. The first confirmed cases of COVID-19 in Indonesian citizens. Public Heal Indones [Internet]. 2020;6(02):70-71

2 Sukmana M, Aminuddin M, Nopriyanto D. Indonesian government response in COVID-19 disaster prevention. East Afrian Sch J Med Sci 2020;3(3):81-86

3 Setiati S, Azwar MK. COVID-19 and Indonesia. Acta Med Indones 2020;52(01):84-89

4 Ariawan I, Jusril H. COVID-19 in Indonesia: where are we? Acta Med Indones 2020;52(03):193-195

5 Wee LE, Conceicao EP, Sim XYJ, et al. Minimizing intra-hospital transmission of COVID-19: the role of social distancing. J Hosp Infect 2020;105(02):113-115

6 Wahab FA, Abdullah S, Abdullah JM, et al. Updates on knowledge, attitude and preventive practices on tuberculosis among healthcare workers. Malays J Med Sci 2016;23(06):25-34

7 Lotfinejad N, Peters A, Pittet D. Hand hygiene and the novel coronavirus pandemic: the role of healthcare workers. J Hosp Infect 2020;105(04):776-777

8 Cheng VC-C, Wong S-C, Chuang VW-M, et al. The role of community-wide wearing of face mask for control of coronavirus disease 2019 (COVID-19) epidemic due to SARS-CoV-2. J Infect 2020;81 (01):107-114

9 Thu TPB, Ngoc PNH, Hai NM, Tuan LA. Effect of the social distancing measures on the spread of COVID-19 in 10 highly infected countries. Sci Total Environ 2020;742:140430

10 Wang $\mathrm{M}$, Han X, Fang H, et al. Impact of health education on knowledge and behaviors toward infectious diseases among students in Gansu province, China. BioMed Res Int 2018; 2018:6397340

11 Pourtois G, Notebaert W, Verguts T. Cognitive and affective control. Front Psychol 2012;3:477

12 Ko N-Y, Lu W-H, Chen Y-L, et al. Cognitive, affective, and behavioral constructs of COVID-19 health beliefs: a comparison between sexual minority and heterosexual individuals in Taiwan. Int J Environ Res Public Health 2020;17(12):4282 
13 Ali S, Noreen S, Farooq I, Bugshan A, Vohra F. Risk assessment of healthcare workers at the frontline against COVID-19. Pak J Med Sci 2020;36(COVID19-S4):S99-S103

14 Gan WH, Lim JW, Koh D. Preventing Intra-hospital infection and transmission of coronavirus disease 2019 in health-care workers. Saf Health Work 2020;11(02):241-243

15 Bhagavathula AS, Aldhaleei WA, Rahmani J, Mahabadi MA, Bandari DK. Knowledge and perceptions of COVID-19 among health care workers: cross-sectional study. JMIR Public Heal Surveill 2020;6(02):e19160

16 Zhang M, Zhou M, Tang F, et al. Knowledge, attitude, and practice regarding COVID-19 among healthcare workers in Henan, China. J Hosp Infect 2020;105(02):183-187

17 Güner RHasanoğlu İ, Aktaş F. COVID-19: Prevention and control measures in community. Turkish J Med Sci 2020;50:571-577

18 Alrubaiee GG, Al-Qalah TAH, Al-Aawar MSA. Knowledge, attitudes, anxiety, and preventive behaviours towards COVID-19 among health care providers in Yemen: an online cross-sectional survey. BMC Public Health 2020;20(01):1541

19 Zhong B-L, Luo W, Li H-M, et al. Knowledge, attitudes, and practices towards COVID-19 among Chinese residents during the rapid rise period of the COVID-19 outbreak: a quick online cross-sectional survey. Int J Biol Sci 2020;16(10):1745-1752

20 Kebede Y, Yitayih Y, Birhanu Z, Mekonen S, Ambelu A. Knowledge, perceptions and preventive practices towards COVID-19 early in the outbreak among Jimma university medical center visitors, Southwest Ethiopia. PLoS One 2020;15:e0233744

21 Ali M, Shah STH, Imran M, Khan A. The role of asymptomatic class, quarantine and isolation in the transmission of COVID-19. J Biol Dyn 2020;14(01):389-408

22 Rachman BE, Rusli M, Miftahussurur M. The hidden vulnerability of COVID-19 observed from asymptomatic cases in Indonesia. Syst Rev Pharm. 2020;11(02):703-713

23 Pedrosa AL, Bitencourt L, Fróes ACF, et al. Emotional, behavioral, and psychological impact of the COVID-19 pandemic. Front Psychol 2020;11:566212

24 Asmundson GJG, Taylor S. How health anxiety influences responses to viral outbreaks like COVID-19: What all decisionmakers, health authorities, and health care professionals need to know. J Anxiety Disord 2020;71:102211

25 Mello AF, Mello MF, Carpenter LL, Price LH. Update on stress and depression: the role of the hypothalamic-pituitary-adrenal (HPA) axis. Br J Psychiatry 2003;25(04):231-238

26 Weston D, Hauck K, Amlôt R. Infection prevention behaviour and infectious disease modelling: a review of the literature and recommendations for the future. BMC Public Health 2018;18 (01):336

27 Bavel JJV, Baicker K, Boggio PS, et al. Using social and behavioural science to support COVID-19 pandemic response. Nat Hum Behav 2020;4(05):460-471 